\title{
Making Liberal Democracy Ethical: Aristotle on the Unity of Ethics and Politics \\ By Chris Berger
}

\begin{abstract}
Contemporary liberal democracy recognizes a fundamental distinction between matters of "public" and "private" domain that amounts to a separation of ethics from politics. Such a distinction is, however, a recent one insofar as the history of political thought is concerned. Political and ethical matters can and in fact have been thought of and practiced as a single project. Aristotle is one philosopher who has approached ethics and politics not as two distinct subjects but as a single unified project: the project of living well. This essay examines Aristotle's ethical-political project and engages with contemporary thinkers who have grappled with Aristotle's political philosophy as a possible remedy for the problems currently confronting liberal democratic politics. It argues that the best remedy for the ills of liberal democracy that arise out of the continued prevalence of relativism in liberal democratic discourse is a re-thinking of liberal education that unites ethical and political considerations. The author contends that Aristotle's political philosophy offers us a vantage point from which this unity may be perceived and, hopefully, implemented.
\end{abstract}

“... for Aristotle, 'knowledge, wisdom, patriotism and virtue' are the result of a certain kind of education, and education aimed at an intrinsic good or a good according to nature, an education that distinguishes the good from the pleasant and the noble from the base. But such knowledge is not, nor can it be, the by-product of arrested evil-doing. An education in virtue cannot be merely a by-product of contingent causality. It must be deliberately pursued for its own sake. The good must be an object of a cognitive process in order to become the compass in the education of the passions. Only when the passions have been disciplined by reason can any government - or any individual - pursue the good. For Aristotle, the only concurrence that counts in the end is that of reason and passion. "1

\section{Introduction}

Contemporary liberal democracy recognizes a fundamental distinction between matters of "public" and "private" domain. This distinction amounts to a separation of ethics from politics. Such a distinction is, however, a recent one insofar as the history of political thought is concerned. Political and ethical matters can and in fact have been thought of and practiced as a single project. Aristotle is one philosopher who has approached ethics and politics not as two distinct subjects but as a single unified project: the project of living well. Contemporary liberal democratic politics, despite its resounding success in securing and providing personal freedoms and undeniably higher material standards of living, nonetheless runs the constant risk of degenerating into a relativism that handicaps the ability of citizens to take seriously the question of what it means to live well. The insistent distinction between ethics and politics, it will be argued, is largely to blame for this drawback of liberal democracy. This essay will examine

\footnotetext{
${ }^{1}$ Harry V. Jaffa. A New Birth of Freedom - Abraham Lincoln and the Coming of the Civil War. (Lanham, Maryland: Rowman \& Littlefield, 2000), 456.
} 
Aristotle's ethical-political project before engaging with contemporary thinkers who have grappled with Aristotle's political philosophy as a possible remedy for the problems currently confronting liberal democratic politics. It will be argued that the best remedy for the ills of liberal democracy that arise out of the continued prevalence of relativism in liberal democratic discourse is a re-thinking of liberal education that unites ethical and political considerations. The argument will seek to show that Aristotle's political philosophy offers us a vantage point from which this unity may be perceived and, hopefully, implemented.

\section{The Difficulty of Studying Aristotle within the Framework of Liberal Democracy}

The serious study of Aristotle with the aim of understanding him not as a relic of exclusively historical interest, but as a potential source of guidance and enlightenment for our own problems and questions, is a proposition of sufficient controversy such that it merits some justification. Prior to delving into Aristotle, this section will explain why we are in need of his help and the help of the ancients more generally in addressing the ills of liberal democracy today.

The ill of liberal democracy to which this essay addresses itself can be reduced, in a word, to relativism broadly conceived. Relativism "broadly conceived" refers to the belief, now dogmatized so as to be virtually unquestionable in modern Western liberal democracies, that truth and moral excellence cannot be universally or objectively defined and are literally relative to time and place, to cultures and individuals. Aristotle, in rejecting the notion that the worth of political and ethical practices are relative to individuals, cultures, or historical epochs, therefore speaks to us from an alien standpoint that is difficult for us to relate to and immediately come to terms with.

As concerns us modern liberal democrats in particular, Aristotle's ethical-political philosophy can seem antiquated and, what is particularly offensive to us, elitist. By contrast, the spirit of modern politics can be characterized, in a word, as progressive. ${ }^{2}$ Implicit in this word is an assumption, whether valid or not, that this age is an improvement over ages past. More to the point, it is an assumption that liberal democratic politics, comprising the thought underpinning it and the regimes guided by it in turn, is decidedly superior to the political thought and regimes of the past. An even more fundamental assumption at the core of this progressive spirit is the possibility of progress as such. The notion of progress lies at the heart of the distinction between ancient and modern political thought. ${ }^{3}$ The ancients, the ranks of whom include Aristotle, did not hope for the "relief of man's estate" as Francis Bacon famously did, ${ }^{4}$ but treated the problems of political life and the human condition (such as the tensions between reason and revelation; politics and philosophy; and opinion and knowledge) as irreducible and permanent. We moderns from Machiavelli onwards break with the ancients precisely on the question of the

\footnotetext{
2 In our terminology, "liberals" hold a monopoly on progressivism while "conservatives" supposedly oppose progress. Juxtaposed against the history of political thought, however, this distinction begins to appear trifling. The shared spirit of both Left and Right in today's liberal democratic politics seeks the equality of man and the flourishing of all; it is the means, not the ends, that differs.

${ }^{3}$ This topic is treated perhaps most famously (according to some, infamously) by the late historian of political philosophy, Leo Strauss. In particular, see: Natural Right and History (Chicago: University of Chicago Press, 1950) and What is Political Philosophy? (Chicago: University of Chicago Press, 1959).

${ }^{4}$ Francis Bacon, The Advancement of Learning, I.V.11
} 
possibility of relieving man's estate. Modernity's fact-value break in the name of positivism is in the name of progress, and what may arguably be called "postmodernity" in the form of historicism/existentialism radicalizes the fact-value distinction to reject fact altogether in favour of an extreme relativism: nihilism. ${ }^{5}$

Where Aristotle saw problems and tensions that are perennial because natural, we moderns see potential solutions in the conquest of nature, both human and otherwise, through value-positing. We hope for a world in which we are all equal, we all have a say in how we are ruled, we all can live as we please, and we all are provided for without scarcity. The radical nature of the change in thought that occurred almost six centuries ago and that has brought us to this point is difficult to overstate. The ethics-politics split that characterizes our politics is inseparable from this shift, as it is a product of the modern scientific method. It is important that we emphasize that modern science is a "method," as opposed to science's Latin root scientia, which refers to "knowledge" and is equivalent to the Greek episteme. What was for the ancients the goal of inquiry has for us become the method or the means by which knowledge is obtained. ${ }^{6}$ For Aristotle, "political science" was literally knowledge of politics and the aim of inquiry into and reflection upon the aims and nature of politics, i.e. the result of political philosophy. Political science for us means something very different from Aristotle's usage: rather than political science being the desired result of political philosophy, the "scientific" study of politics has largely supplanted political philosophy. And in our scientific method of studying politics we distinguish, thanks to positivism, between "facts" and "values." Scientific knowledge of facts is possible; the same cannot be said about values, which, we believe, do not admit of empirical judgment. Values are relative. ${ }^{7}$ Historicism/existentialism radicalizes this idea by abolishing facts entirely, reducing ethics and politics alike to the rigorous positing of values in the name of "authenticity."

The "fact-value" distinction poses both theoretical and practical problems that afflict both the practices of liberal democracy and our ability as liberal democrats to take the Aristotelian

\footnotetext{
5 This essay's understanding of the history of modern philosophy and political thought is indebted to the works of Leo Strauss, and in particular his tracing of modern

historicism/existentialism back through positivism and ultimately to the initial break with antiquity by the early modern philosophers. See especially: Natural Right and History (Chicago: University of Chicago Press, 1950).

${ }^{6}$ Leo Strauss points out, compellingly, that the ancients were remarkably aware of the possibility of what would become the modern conception of science, but that they ultimately rejected it as unbecoming of human beings, destructive of their humanity, and susceptible of application by tyrants ("Restatement on Xenophon's Hiero" in On Tyranny [Chicago: University of Chicago Press, 2000], 178). In support of this contentious claim he directs our attention to passages in Aristotle's Physics, Plato's Theaetetus, and Xenophon's Memorabilia.

${ }^{7}$ Regardless of the apparently vast divide between the Left and the Right today, they are ultimately two sides of the same modern coin. The disagreement between the two is due to a more fundamental agreement that they share: that the good is a product of value judgments. Neither Rick Santorum nor Michael Moore can express his political position without speaking of values: this is the terminology that betrays the elemental assumptions that make us moderns rather than ancients. Indeed, even the connotations that surround "ancient" and "modern" show us to be predisposed toward the latter over against the former as a matter of course: we deem the latter progressive and rational, the former reactionary and irrational.
} 
alternative seriously. Values are things pertaining to that which makes us happy: e.g. the Beautiful, the Good, and so on. As values, we relegate these things to individual taste and preference and say: "to each his or her own." We profess the right of each to pursue happiness as he or she understands it, so long as that pursuit does not infringe on the right of others to do the same. Ethics, as a result, is private and subjective or relative, while politics and the science that studies it concern the institutional administration of things. What often goes unacknowledged in modern political science is that the fact-value distinction is itself the product of a value judgment that says that values ought to be left up to their possessors, that we ought not to infringe on the right of others to their own values, and that it is facts and only facts that ought to be the object of intellectual inquiry. Relativism poses not only intellectual problems for us (i.e. the clear logical contradiction in claiming that "there is no objective truth"), but political difficulties as well; if values are indeed relative, then there are no grounds on which our valuerelative regime may be defended as intrinsically more just than one that does not respect a plurality of values.

In Aristotle, by way of contrast, happiness is the final good that is desired for its own sake, ${ }^{8}$ and human beings as political animals by nature can achieve happiness by fulfilling that nature. Following this, the political community is a partnership that aims at "the most authoritative good of all," i.e. happiness. Therefore, the end of politics is happiness for the members of a political partnership, and political science, as knowledge of political things, is the science of happiness. For Aristotle, then, those things we have come to call "values" are in fact at the centre of the science of politics as originally understood. A science of politics that has nothing to say about "the good" because it deems these assessments to be mere "value judgments" is then radically un-scientific, though this irony appears to be lost on we modern political scientists. A political scientist that cannot distinguish good from bad, or just from unjust, might just as well be a doctor that cannot distinguish healthy from sick. Aristotle can help us to clarify what we seek to understand via political science and more pressingly, what we seek to accomplish in living as members of the political partnership. Rather than denounce Aristotle as an elitist, we can practice the openness on behalf of which we so enthusiastically pontificate, and consider the possibility that his political science is indeed more scientific than our own in holding liberal democracy to a standard that rises above the relativistic split of ethics and politics.

\section{Aristotle on Ethics and Politics}

Aristotle's most overtly political work, The Politics, is in fact neither the only nor the last word on Aristotle's political project. Absolutely key to understanding Aristotle's political science is an understanding of the Nicomachean Ethics, wherein Aristotle addresses the question of what it means to act and live well. The precise relationship between these two treatises is not merely one of ethics influencing politics or vice versa, but is in fact an outline of ethical politics. The account of the virtues in the Nicomachean Ethics and the definition of the political community in the Politics will be outlined before moving on to analyze their contemporary relevance in light of the interpretations of modern thinkers. This section will seek to show via an exposition of Aristotle's arguments that Aristotelian ethics are not only useful but crucial for educating and moderating politically engaged citizens. As it concerns us specifically, whatever

\footnotetext{
${ }^{8}$ Nicomachean Ethics 1093a26-1094b11

${ }^{9}$ Politics 1252a1-6
} 
the great strengths of liberal democracy, the relativism it can lean towards strips moderation and responsibility of its power to direct citizen engagement. ${ }^{10}$

In the Nicomachean Ethics, ${ }^{11}$ Aristotle lays out his plan for an architectonic science, that is, a science of that which is good and choice worthy for its own sake and not for the sake of any further good. The science of politics is the architectonic science because it is concerned with the human good, that is, with that which is most needful; political science governs the aims of all other sciences because it is concerned with what is good for its own sake. ${ }^{12}$ Happiness as "a certain activity of soul in accord with virtue" is sought for its own sake, and is the fulfillment of the human function, i.e. the state of a human being who is doing well that which a human being is naturally fitted to do. ${ }^{13}$ Aristotle identifies three ways of life that people hold to be conducive to happiness: the life of pleasure; the political life; and the contemplative life. The life of pleasure can be dismissed as fit only for "fatted cattle," and moneymaking is only ever for the sake of something else, so it cannot in itself conduce to happiness. ${ }^{14}$ The political life can aim toward either honour or virtue; honour is not sufficient for happiness as it is bestowed upon oneself by an external source and thereby precludes self-sufficiency. ${ }^{15}$ The political life is then one of virtue, though virtue alone may not be enough to secure happiness if one is afflicted with great misfortune. ${ }^{16}$ If it may be posited that happiness is the goal toward which the political art points, then the complex question of what exactly this activity of the soul consists is only further complicated when, in the latter parts of the Ethics, we are presented with the contemplative life as a possibly viable alternative for the attainment of full happiness.

However, as concerns the political life, virtue is held by Aristotle to be the defining component, and the discussion of virtue constitutes the bulk of the Ethics. That the book is intended first and foremost for those who are most likely to lead political lives (i.e. the gentlemen or those with leisure) is implicit in the evident assumption that the reader takes the desirability of moral virtue for granted. There is no argument given in the Ethics for why virtue is politically pertinent, or for why virtue is a good thing for a person to possess, exhibit, and practice. More explicitly, the life of pleasure or moneymaking is dismissed, and the contemplative life is only very briefly discussed over the course of three chapters in the final book of the Ethics. ${ }^{17}$ Finally, as Aristotle indicates, political science is most properly fitted for those who are more mature; the young are ill-suited for undertaking political science because of their excessive passions, and so it is those who are in some sense already virtuous who are fitted to think about virtue, the end of politics. We see that the life of virtue is a political one, and therefore that the project of politics is a project of inculcating virtue.

\footnotetext{
${ }^{10}$ For an incisive study of the problems inherent in reckless engagement in democratic politics and the danger of immoderation in political thought, particularly in the $20^{\text {th }}$ century intelligentsia, see: Mark Lilla The Reckless Mind: Intellectuals in Politics (New York: The New York Review of Books, 2001).

${ }^{11}$ Henceforth referred to simply as "the Ethics."

${ }^{12}$ Nicomachean Ethics 1093a26-1094b11

${ }^{13} 1199 \mathrm{~b} 25-26$

14 1095b20, 1096a5-10

15 1095b24-29

16 1096a1-3

${ }^{17}$ Bk. 10.6-8
} 
Aristotle lays out a conception of virtue that has two parts: one moral, the other intellectual. The moral virtues are eleven in number: courage, temperance, generosity, magnificence, magnanimity, ambition, gentleness, friendliness, truthfulness about oneself, wittiness, and justice. Intellectual virtue, on the other hand, is composed of five powers by which truth is attained: art, science, prudence, wisdom, and intellect. These two classes of virtue reflect the soul's division into rational and the non-rational parts. The ultimate relation between the non-rational and the rational, or the eleven moral virtues and the five means of contemplating and obtaining truth, is ambiguous. Where politics fits within or in relation to the rational and non-rational parts of the soul is thus a further question that must be posed in thinking about how ethics and politics fits together for Aristotle.

By beginning where Aristotle does, i.e. with moral or non-rational virtue, we can find a pattern in the role and significance of the various eleven virtues. For Aristotle, the moral virtues are acquired through an active process of learning and habituation. ${ }^{18}$ Moral virtues are a result of rigorous self-training, thus they are neither taught nor are they natural capacities with which one is born. There is, therefore, a difference between a virtuous act and the state of being virtuous. To be truly virtuous is to derive pleasure from acting virtuously; virtue is not an ascetic notion for Aristotle. As such, restraint as the overcoming of pain is inferior to virtue as the derivation of pleasure from experience in the performance of virtuous acts; one who exercises restraint falls short of true virtue. We see more clearly at this point why the moral virtues pertain to the nonrational capacity of the soul in that the experience of pleasure, the non-rational experience, is inseparable from moral virtue; pleasure is overcome in becoming virtuous, and experienced once one has become virtuous. Moral virtue has to do with the education and direction of the experience of pleasure.

The peak of these moral virtues is magnanimity or greatness of soul; the magnanimous human being is worthy of great honours and knows it. The four preceding moral virtues in Aristotle's list, namely courage, moderation, liberality, and magnificence, ascend from lesser to greater matters to culminate in greatness of soul. Courage is the overcoming of danger to oneself; moderation, the temperate restraint of appetite and desire; liberality, the generosity one shows toward others in accordance with one's means; and finally, magnificence is essentially the virtue of the liberal human being with greater means by which to spend on greater things. The magnanimous human being, like the magnificent human being, is concerned with great things, but greatness in the case of greatness of soul is not limited to the spending of large amounts of money on grand projects, acts of charity, or whatever else. The magnanimous man is concerned with the unsurpassed nobility and honour of his deeds.

If magnanimity is indeed the peak or culmination of the moral virtues, we might then wonder why this supposed peak of the moral virtues does not appear at the end of Aristotle's list. However, we find that the nature of the great-souled human being presents certain difficulties. The magnanimous man, as the greatest man, must exhibit all of the moral virtues, but it is questionable whether magnanimity is the peak of human excellence as such. Upon scrutiny, it becomes evident that the magnanimous man, despite remembering what he has done to benefit those lesser than him, nonetheless tends to forget favours done him by others. As a result, magnanimous people are difficult to integrate into the political order. It seems to follow from the characteristics of greatness of soul that one who is magnanimous will only ever "stoop" to the affairs of the city in crisis situations in which one's greatness in bestowing benefits unto a

${ }^{18}$ Ethos may be roughly translated as "habit."

The Agora: Political Science Undergraduate Journal Vol.3 No. (2013) 
community of people will be widely recognized and lauded. Political engagement will only be worthwhile for the magnanimous human being if great honours are the reward. That the magnanimous human being is politically difficult seems to account for the moral virtues listed after magnanimity.

The virtues of ambition, gentleness, friendliness, truthfulness about oneself, wittiness, and justice are the "post-magnanimity" virtues, and appear to be more "political" in nature than magnanimity and the virtues preceding it in Aristotle's list. The virtue of proper ambition disposes one to "seek honour from where and in the way one ought," thus taming the unbridled spiritedness that may make one overzealous in acquiring status, reputation, and admiration. ${ }^{19}$ At first glance, it would appear that this virtue of ambition fits into greatness of soul; the greatsouled human being pursues only those honours that are truly great. However, it is not so clear that the greatest of honours are to be identified with those honours that are to be sought "where and in the way one ought." The greatest honours may be at odds with the good of the political community. Indeed, as has been seen, the great-souled person is in a sense apolitical in aspiration. A similar tempering effect is found in the virtue of gentleness, i.e. the virtue of the correct disposition vis-à-vis the passion of anger. Insofar as the necessity of a virtue that tempers honour-seeking is concerned, the "decline" from greatness of soul seems to indicate the impossibility or even undesirability of a great-souled person in politics.

This decline would seem to suggest that the magnanimous man's desire for recognition is in practice a desire for recognition from those who are lesser to the magnanimous man in moral, political, or noble standing. The political reality is that any recognition the magnanimous man receives will be given by his inferiors, hence robbing him of the full satisfaction of the recognition he believes he deserves. While the virtue of ambition ideally moderates the pursuit of honour, the virtue of gentleness moderates the reaction of one who does not receive the honour that one believes one deserves. Aristotle is ambiguous as to precisely what is worthy of an angry reaction and what is not, though in reference to his mentioning that virtue is more characteristic of the political than honour is, it would seem that anger is a fitting response to vice, and perhaps less so with regard to perceived dishonor.

Friendliness for Aristotle is a virtue exercised in our relationships and interactions with the people around us, specifically "in living together and in sharing in speeches and actions." 20 The friendly person neither flatters nor is anti-social. Similar to friendliness is truthfulness about oneself in that one who is truthful about oneself is neither boastful nor ironic, that is, one who is truthful in this way neither flatters nor denigrates oneself. Wittiness, the mean between buffoonery and boorishness, pertains to matters of speaking with others in leisure. ${ }^{21}$ These three virtues are political in a less obvious way. All three have to do with relating to those around oneself, and specifically, relating to those around oneself through speech or logos, the distinctively human capacity. ${ }^{22}$ Friendliness self-evidently conduces to friendship, the building blocks of the political partnership of the city in grooming individuals to look to the good beyond themselves. $^{23}$ Truthfulness about oneself and wittiness appear to be safeguards against political hubris; boastfulness and irony undermine political responsibility by directing one's attention to

$\begin{array}{ll} & 1125 \mathrm{~b} 9 \\ { }^{20} & 1126 \mathrm{~b} 13 \\ { }^{21} & 1128 \mathrm{a} 1-5 \\ { }^{22} & \text { Politics } 1253 \mathrm{a} 8-9 \\ { }^{23} & 1152 \mathrm{~b} 26-30 ; \text { Nicomachean Ethics } 1172 \mathrm{a} 5-7\end{array}$

The Agora: Political Science Undergraduate Journal Vol.3 No. (2013) 
honours and causing one to hold politics in contempt, respectively, while buffoonery and boorishness compromise the sanctity of law and undermine the grounds for friendliness, respectively.

The final and most expressly political of the moral virtues is justice. As opposed to the Socratic conception of justice as the proper ordering of the soul, Aristotle's justice occurs only in relation to others under law within a political community. Justice is the proper relation between citizens, i.e. equals, hence there can be justice between husband and wife, but not between parent and child. ${ }^{24}$ As justice exists in relation to others, Aristotle agrees at least in part with the Thrasymachean thesis laid out in Plato's Republic that justice is the good of another. ${ }^{25}$ Justice for Aristotle can be understood as both a complete virtue and as a particular virtue. As complete virtue, justice is following the law; as a particular virtue, justice is conducting oneself in a manner that is equal or fair with respect to others. Justice as complete virtue is political in following the law because the law seeks happiness for the community; good laws are laid down by a political community in order that all of the moral virtues may be cultivated. Justice in this sense is complete virtue in relation to others, thus it is moral virtue practiced politically.

The case of justice points most explicitly to the unity of ethics and politics in Aristotle's philosophy. Justice exemplifies the need for the help of and interaction with others in the cultivation of the moral virtues with the aim of developing good character, i.e. well-constituted souls. These necessary relations are not simply social, however. Rather, in Aristotle's words, "man is by nature a political animal," and not merely a social one. ${ }^{26}$ Man is not alone in being a social creature, thus his sociability cannot be identical with his humanity. However, man is alone in the possession of logos. This unique and defining trait of human beings, insofar as it defines what it means to be human, is the key to human nature as a political being. Humans do not merely live together as any number of other animals do: rather, human beings live together in cities. The city is the partnership that "aims at the most authoritative good of all.",27 Human beings live together as thinking, speaking beings in that their sociability and logos combine to make the political community one in which citizens deliberate in common about the good and the good life. ${ }^{28}$ The good life, of course, is the life of actually being good, that is, the life of practicing virtue. The political community is indispensable in guiding its citizens toward virtue; indeed, determining and inculcating virtue is the task of the political community.

${ }^{24}$ Husband and wife rule the household in common (as citizens of the good regime partake of rule of the city in common) while children are ruled by parents and have no stake in rule.

${ }^{25}$ Plato Republic 339b

${ }^{26}$ Politics $1253 \mathrm{a} 2$

${ }^{27} 1252 \mathrm{a} 5$

${ }^{28}$ There are highly intelligent and highly social non-human animals, to be sure, but that they do not possess $\log o s$, or capacity for deliberation about the good and how to live, is made clear by a very simply observation: one pod of dolphins, for example, is virtually identical to any other pod of dolphins; they all live in the same way. That human beings reason and deliberate about the good is made clear by the equally simple observation that different communities, and different individuals within those communities, disagree about the good, hence polities exhibit profound and conflicting differences in what they take to be the most important things. The highest conflicts between individual non-human animals concern feeding and mating, while those between groups of such animals concern territory. Ways of living and opinions of the good are not up for discussion, let alone dispute as they are amongst human beings.

The Agora: Political Science Undergraduate Journal Vol.3 No. (2013) 
A word must also be said about Aristotle's conception of friendship. All three types of friendship, namely friendships of pleasure, utility, and virtue (or true friendship) play an observable role in the functioning of the community as partnership. The end of the city is happiness, and "he who will be happy will need serious friends." 29 These "serious" friends are those who are like-minded, and furthermore, are those who are not base, thus presumably virtuous since "it is impossible for base people to be like-minded." 30 This like-mindedness is said by Aristotle to be a form of "friendship,"31 in that those who are like-minded "aim at [what is just and advantageous] also in common." ${ }^{32}$ It would seem that the most political friendship is the one grounded in what is most just and most advantageous, that is, the true good; hence the most political friendship is the true friendship of those who are friends in virtue and care for one another as they care for themselves. The political community transcends friendships of pleasure and utility. The good political community will foster the conditions under which virtue-based friendships are possible, thereby cultivating an ethics-based civic partnership concerned with human excellence. As Aristotle concludes the Politics, "the legislator must, therefore, make the education of the young his object above all," and "where this does not happen in cities it hurts the regimes." 33 It is telling that the final word on the question of living well concerns education, thus capping off the two-part inquiry of the Nicomachean Ethics and the Politics.

\section{Ethics, Politics, and Liberal Democratic Practice}

Liberal democracy in the form in which we live today draws a sharp distinction between public and private, political and ethical. Allan Bloom was astute when he characterized modern politics, in both its practical and scientific forms, as a politics of "values" that separates the factual administration of things from the individual's "lifestyle," "life choices," "relationships," or "culture"; values are produced, not arrived at by reason. ${ }^{34}$ As we have noted, such a language of "values" as understood in opposition to facts represents a radical break from the political science of Aristotle which, to put it in modern liberal terminology, posits values that are factually knowable or facts that may be intrinsically valuable.

Is there a problem with this break? Are there political benefits to be had in reconsidering Aristotle's ethical-political project? This section, with reference to contemporary thinkers who have grappled with this same question, will argue that there are tangible reasons to rethink our way of doing and educating for politics, and moreover, that Aristotle provides us with a point of departure that helps us to do just this. Not only does Aristotle provide us with "an otherwise unavailable critical perspective on the present" thanks to his great distance from us in time, he speaks in his own right to the specific questions and dilemmas that arise out of our politics. ${ }^{35}$

In order to justify a rethinking of our way of doing politics, it must first be shown that there is something in our way of doing and envisaging politics that is deficient in some sense. Indeed, the fact-value distinction and subsequent moral and cultural relativism that has become

\footnotetext{
${ }^{29}$ Nicomachean Ethics $1170 \mathrm{~b} 18$

${ }^{30} 1167 \mathrm{~b} 9-10$

$311167 \mathrm{~b} 3$

${ }^{32} 1167 \mathrm{~b} 9$

${ }^{33}$ Politics 1337a10-13

${ }^{34}$ Allan Bloom. The Closing of the American Mind, (New York: Simon \& Schuster, 1987), 201.

35 John R. Wallach. "Contemporary Aristotelianism” in Political Theory (Vol. 20, No. 4, 1992), 613.
} 
pervasive in liberal democratic politics are indeed politically and psychologically (in the classical sense) harmful phenomena - indeed, they are apolitical phenomena. This separation of public and private and the subsequent assertion that the private is to be left to the subjective, relative discretion of the autonomous individual's value-positing activity makes the autonomous, subjective individual the be-all and end-all of the good. ${ }^{36}$ This idea is fundamentally at odds with Aristotle's idea that "the good of . . . a nation and of cities is nobler and more divine [than the good of the individual alone]," though he nonetheless provides for the good of an individual being "desirable enough" in its own right. ${ }^{37}$

If one accepts that Aristotle posits the unity of ethics and politics, it must be noted that good ethics and good politics necessarily go hand in hand. The political community, and more specifically the political community that effectively secures the happiness of the community by promoting virtue, is necessary for the existence of virtuous citizens. Likewise and as a matter of course, insofar as they are virtuous human beings, citizens definitionally compose a political community by practicing complete virtue, i.e. justice, in relation to one another. The political community arises out of the development and exercise of virtue, which in turn requires this interaction with others if virtue is to be habituated through actual practice. A political community that holds the free and subjective individual to be sacrosanct is then seen to be opposed in some sense to moral virtue. In a liberal democratic state, it would appear that the question of politics and ethics becomes an either-or question: in a liberal democracy, good politics consists in upholding the sacred autonomy of the individual qua individual, while there is no set standard for ethics. Since there is no such standard mandated by the political community, ethics is thus left to the subjective discretion of the individual to be developed privately, that is, apolitically. Ethical practice is a lonely affair in a liberal democracy, while a publicly hence politically active one for Aristotle. Indeed, it is a serious question whether ethics as originally understood is possible in a liberal democracy.

There are real reasons to be skeptical of positive answers to this question. Charles Pinches is one contemporary theorist that has suggested that liberalism and virtue are at odds. However, he does not despair of the possibility of virtue in a liberal democracy, though the type of virtue possible is not clearly applicable to the aim of rationally grounding virtue ethics in politics. ${ }^{38}$ Indeed, Pinches argues from a Christian theological standpoint that "liberalism as a political system has a need for virtue among its citizens if it is to be sustained." ${ }^{39}$ In contemporary political discourse, the proposition that morality ought to be reinserted into the political sphere will call to mind images of the religious right, be it in the form of Islamism, Christian fundamentalism, or otherwise. Indeed, many calls for an overhaul of public and private morality emanate from this political and spiritual camp, hence its assertions cannot be entirely ignored in a consideration of the relationship between ethics and politics. Nonetheless,

\footnotetext{
${ }^{36}$ This reminds us of the Protagorean thesis that man is the measure of all things; in the modern jargon we might call this "perspectivism." For explications of Protagoras' thought and particularly his maxim, "Man is the measure of all things," see Plato's dialogue Protagoras and Diogenes Laertius' Life of Protagoras.

${ }^{37}$ Nicomachean Ethics 1094 b10

${ }^{38}$ Charles R. Pinches. "Liberalism's Need for Virtue and Christian Theology" in Aristotle and Modern Politics. ed. Aristide Tessitore. (Notre Dame, Indiana: University of Notre Dame Press, 2002), 227.

39 Ibid 215.
}

The Agora: Political Science Undergraduate Journal Vol.3 No. (2013) 
serious thinkers such as Pinches offer more sober arguments for a theological call to virtue that avoids the emotive and aggressive tone of religious extremism. In seeking to explore the possibilities of injecting virtue ethics into politics on rationalistic grounds, it behooves us to consider the adequacy of such arguments.

Pinches contends that liberalism has tended to "instrumentalize" virtue; virtue for its own sake is a foreign notion as far as liberalism is concerned. ${ }^{40}$ The idea that liberalism requires virtue in order to sustain itself may seem a strange one at face value, particularly to liberals. While Pinches' concern lies more with the role and implications of Christianity and its brand of virtue, there is a case to be made that virtue as such is required for a healthy liberal democracy despite the apparent contradictions between virtue ethics and liberalism.

It must be noted, however, that Pinches' Aristotelianism can only help us to the extent that he points us toward the possibility and necessity of virtue in liberal democracy. Unfortunately, he does not point us to full human flourishing within an ethical liberal democracy; the theistic divide between this life and the next contributes to a restriction on the prospects for a "virtuous" regime. For someone like Pinches, virtue is never sufficient in itself, as it can never, from a Christian standpoint, overcome original sin. ${ }^{41}$ In this sense, Pinches' particular theological approach does not ultimately help us to unify human excellence and politics, as the consideration of sin separates ethics from human excellence. It is only in this way that Pinches' Aristotelianism unites ethics to politics: ethics and politics are literally mundane, or part and parcel of the corrupt human world. True excellence, thanks to our sin, is not humanly possible.

Harvey Mansfield offers a succinct and helpful summation of the key difference between Christian virtue and the classical pagan virtue of the Greeks by way of the example of Augustine: "Augustine wanted to make the point that moral virtue, contrary to Aristotle's glowing picture, is always tainted with human self-interest, and always in need of God's grace." 42 Pinches reflects this Augustinian and more broadly Christian formulation of true virtue as praactice of the tenets of Christianity as laid down in the revealed word of the Bible. For the classics, virtue is thisworldly as opposed to tied to an afterlife of just desserts, thus Christian theological virtue as communicated by Pinches cannot be ethical and political in the way that Aristotelian virtue is. True Aristotelian virtue is intrinsically pleasurable and worthwhile for its own sake; Christian virtue is for the sake of something else, namely pleasing God and securing reward while avoiding punishment in life after death. As a result, this approach to instituting virtue ethics is fatally dependent upon a polity's citizenry agreeing upon a certain theological teaching of virtue, a dependency that cannot be afforded in a regime as pluralistic and diverse as our liberal democracy. We must look elsewhere for a unity of ethics and politics that allows for the human flourishing in this world that is our goal.

On paper, virtue is at least possible in a liberal democracy because the upholding of the autonomous and subjective individual, despite its aversion to enforcing a conception of virtue, paradoxically makes space for the study and practice of “objective" virtue. Much as Plato's Socrates points out that democracy allows for - but does not necessarily foster - the best way of

\footnotetext{
${ }^{40}$ Ibid $210,215$.

${ }^{41}$ Ibid 224.

${ }^{42}$ Harvey C. Mansfield, A Student's Guide to Political Philosophy (Wilmington: ISI Books, 2001), 24 .
} 
life because it allows for everything, ${ }^{43}$ so modern liberal democracy, in leaving all life choices up to the subjective individual, leaves open the possibility that the individual may choose the life of virtue. On the theoretical level, this defence of the liberal democratic approach to virtue seems sound. However, Aristotelian virtue requires practice, and this in turn requires other people. It is therefore a problem that private practices and "values" are left to the sole discretion of the individual in a liberal political community because it is unlikely that any two individuals will come, on their own, to share a conception of virtue such that they may act in accordance with it toward one another.

Cultivating the conditions conducive to the practice of virtue in relation to one another is ultimately a question of education, and Aristotle's conception of friendship is helpful to us in addressing this problem. For the classics of antiquity, education, derived in English from the Latin educare (literally "to lead" or "to lead out"), evokes strikingly the imagery of Plato's Cave and the prisoner's assent out of it. ${ }^{44}$ Education is the leading upwards of a human being to freedom of mind. Hence it is the forming of the whole human being such as to improve him. Ideally, the result is that the educated human being joins the ranks of the aristoi or "the best" (from which we derive "aristocracy," or rule of the best). Hence the twentieth-century thinker Leo Strauss, a great defender and theorist of liberal education, has suggested that "liberal education is the necessary endeavor to found an aristocracy within democratic mass society."45 Liberal education is necessary for a healthy liberal democracy in that it transcends the directionless subjectivism of the mass society of autonomous individuals and points to "democracy as originally meant," i.e. democracy understood as "an aristocracy which has broadened into a universal aristocracy." 46 Though Strauss does not directly reference Aristotle by name in this context, this idea of democracy as "originally meant" bears great resemblance to Aristotle's regime species "politeia," or the form of rule by many that, thanks to the antidemagogic temperance of its aristocratic components, looks to the good of all (inclusive of the elite minority) and not exclusively to that of the ruling many (the exclusive concern for which is the hallmark of democracy). Polity, as the rule of citizens, i.e. true equals, is the rule of friends properly understood. A polity composed of friends ruling for the good would indeed be an aristocracy broadened so as to be universal.

An aristocrat is a ruler who rules by virtue of being the best, that is, by virtue of being virtuous. Aristocracy as a regime takes the "private" virtue of the good human being and expands it to the sphere of the "public" in creating a regime in which a community is ruled by what is best in it. A "universal" aristocracy, that is, a true democracy as originally understood, would then seem to show most explicitly the intimate relationship connecting ethics and politics in that the ethical sphere and the political sphere have become not only harmonized but in a sense melded into one another. Hence, as Strauss observes, Aristotle "rejected a view of the city which seems to foreshadow the modern view of political society and hence the distinction between state and society." 47 In the modern view, "society" is composed of individuals who pursue happiness according to the diverse understandings of each; as these understandings may

\footnotetext{
${ }^{43}$ Plato Republic 561b-e

${ }^{44}$ Republic Bk. VII

${ }^{45}$ Leo Strauss. Liberalism Ancient and Modern. (Chicago: University of Chicago Press, 1995), 10 .

${ }^{46}$ Ibid 4.

${ }^{47}$ Leo Strauss. The City and Man. (Chicago: University of Chicago Press, 1978), 32.
} 
and almost always do conflict with one another, the state ensures the fundamental conditions under which individuals pursue happiness with minimal occasion for conflict with one another. ${ }^{48}$ In order to find what is commonly requisite to all the myriad understandings of happiness (the conditions for basic life and survival) we must reduce the horizon to the concern for food, health, shelter, and so on. Therefore politics becomes "derivative from the "economic"; politics comes to be regarded as dealing only with the lowest common denominator, since a mass of autonomously and individually conceived notions of happiness is unlikely to come to any common understanding for which the state can provide "higher" preconditions, such as a shared conception of liberal education or virtue ethics. The preconditions for survival and basic freedom alone lay no grounds for education curricula (beyond basic literacy and mathematics, if that) or conventionally defined morality.

Short of prescribing practical ways in which ethics and politics can be merged as projects in our contemporary liberal democracies, it can at least be shown that such unification is desirable and possible. Admittedly, there is reason to be skeptical of the extent to which education suffices for reforming and directing the political community at large toward concern for virtue. In discussing the Nicomachean Ethics, Ronna Burger notes that "the support for justice comes primarily not from moral education but from the law with all its sanctions."49 Indeed, the necessity of law as the stick to education's carrot "constitutes the transition from Aristotle's Ethics to his Politics," as Strauss puts it, and this necessity sheds further light on the intertwined relationship between ethical and political practice. ${ }^{50}$ Indeed, this necessity demonstrates a kinship between the two in that it apparently reveals a shared fundamental shortcoming of ethics and politics: moral education and the politics that help to facilitate education are ultimately insufficient in themselves for nurturing a morally virtuous human being. Indeed, education may be insufficient insofar as it requires something prior to itself. What education seems to presuppose is law in a certain sense, and more specifically, law that lays down or perhaps even mandates if not the substance of education itself, at least the preconditions that are conducive to education. ${ }^{51}$

At first glance, we appear to find ourselves in a chicken-or-egg conundrum in attempting to determine whether education produces good laws, or if it is good laws that formulate and prescribe the appropriate education. In solving this apparent problem, the possibility of an

\footnotetext{
${ }^{48}$ Ibid 31-32.

${ }^{49}$ Ronna Burger. Aristotle's Dialogue with Socrates: On the Nicomachean Ethics. (Chicago: University of Chicago Press, 2008), 93.

${ }^{50}$ Leo Strauss. The City and Man. (Chicago: University of Chicago Press, 1978), 23.

${ }^{51}$ In his Poetics, a treatise often neglected in political science but that is in fact an appendix of sorts to his Politics, Aristotle writes that "the task of the arts of politics and rhetoric in treating the way we speak" is "to be able to say what is the case and what is fitting" (Poetics 1450b5-9). This alludes to the tenth chapter of the tenth book of the Nicomachean Ethics, wherein it is explained that political speech is able to distinguish those who are motivated by what is noble and those who comply with the law out of fear; this contrasts with rhetorical speech, which denies any such distinction and claims that speech in itself is all-powerful, and that legislation is nothing more than the expressed collection of widely esteemed laws (Nicomachean Ethics 1179a33-1181b24). Aristotle's jurisprudence then relies upon political speech in seeking to promote laws that instill concern with honour and virtue; rhetorical speech alone cannot lay the groundwork for an education toward virtue.
}

The Agora: Political Science Undergraduate Journal Vol.3 No. (2013) 
ethical-political project is revealed. Miriam Galston, following Aristotle, argues that law is in fact ill-suited for dealing with problems that show themselves to be quite fluid in reality. Since "human conduct is not and cannot be captured by absolute, universal rules," some form of common deliberation is needed to deal with real-world situations, according to so-called "middle way" theorists. ${ }^{52}$ Such theorists bear this label due to their attempt to carve out a mean between absolutism and relativism that preserves the solid ground of "knowledge" while simultaneously providing for the vicissitudes of day to day and place to place "reality." 53 Aristotle indeed appears to be a source of support for such an approach to legal theory. The nature of the Aristotelian virtues as means or "middle ways" in their own right suggests that the grounds for human excellence require us to conduct ourselves with due consideration for circumstances that are constantly in flux. Indeed, the complete virtue of justice is not an exclusively internal, solitary practice or static state of being, but is defined by action in relation and with reference to others; complete virtue seems to be a dynamic thing.

However, as Galston notes, the deliberative model of democracy that would have political standards set by discussion alone does not find support in the thought of Aristotle. The premise of the deliberative model is that individuals are more likely to respect and abide by rules that they have had a hand in making. Inclusion and participation, according to this view, are good for their own sakes, and so standards come about not by being imposed by external laws but by the interaction of dynamic discussion. There may be a tension in this account, however. We may posit along with someone like Jurgen Habermas a sort of "ideal speech situation" wherein all those impacted by the results of decision-making are included in the decision-making process, ${ }^{54}$ but the problem remains that would-be participants need to want such a deliberative setting in which discussion can take place. If such spaces are to come into being, they must be imposed. Furthermore, this model of an ideal speech situation presupposes that all those concerned want to participate. It may very well be the case that participation in these deliberative spaces changes and transforms people, and it is undeniably the case that those who live only in private spaces do not undergo the ethical transformation made possible by the opportunity to practice virtue in relation to one another, but the imposition of such spaces fall short of unifying ethics and politics insofar as they cannot compel participation.

Aristotle does not fall into this difficulty. Galston correctly observes that Aristotle does not put stock in any and all opinions, but in opinions commonly held by the many as being more likely to offer a base from which to ascend to better opinions and, hopefully, arrive at knowledge at the end. ${ }^{55}$ Deliberation and participation are not simply for their own sakes; they are means, and are subject to judgment based upon their results. Consensus is an unrealistic and perhaps even undesirable goal, and we cannot rely on participants being morally virtuous actors. ${ }^{56}$ Hence it can be extrapolated that we cannot assume that deliberation will transform people for the better; pernicious opinions and incompetent participants may and often enough do carry the day

\footnotetext{
${ }^{52}$ Miriam Galston. "The Middle Way: What Contemporary Liberal Legal Theorists Can Learn from Aristotle" in Aristotle and Modern Politics. ed. Aristide Tessitore. (Notre Dame, Indiana: University of Notre Dame Press, 2002), 235.

${ }^{53}$ Ibid 234.

54 Ibid 242. For Habermas' original thesis, see: The Theory of Communicative Action, Vol. 1: Reason and the Rationalization of Society. (Boston: Beacon Press, 1984), esp. 26-42.

${ }^{55}$ Ibid 238-239.

${ }^{56}$ Ibid 242-243.
} 
if literally any and all opinions are up for deliberation; surely proponents of consensus-based models would change their tune if the majoritarian accord arrived at were to be manifestly vicious. ${ }^{57}$ There is a qualitative difference in Aristotle's thought between action in its own right and correct or virtuous action; vice may be habituated as easily, or probably even more easily than virtue. To put it very crudely, despite the merits of deliberative participation (which appear to be quite limited), it seems that participation for the sake of participation directs attention entirely toward politics while suppressing ethics, or "quality" of action. It is doubtful whether this is much of an improvement over liberalism's emphasis on the private individual and the suppression of the political or public that it entails.

Having found that deliberation in its own right ultimately does not solve the educationlaw problem, it is nonetheless to be noted that by rejecting deliberation alone as the remedy we clarify what is meant by education for Aristotle. In her examination of Aristotle's treatment of education, Mary Nichols observes that education is not the suppression or conquering of nature but rather, by being made possible by nature, education directs and moderates nature. ${ }^{58}$ Education is possible by nature as seen in Aristotle's teleology; the perfected human being is the most natural human being. Therefore, the tempering and direction of the non-rational part of the soul by the rational part is the perfection of nature in the human being insofar as $\log o s$ is developed as the uniquely human capacity. Nichols argues that "the education that Aristotle recommends will keep before human beings the tasks, often conflicting, of developing their diverse natural capacities," and in this sense education is political in that it starts from the differences among capacities of human beings, the basis of the naturalness of the city. ${ }^{59}$

Ultimately, "law is not an imperfect substitute for the absence of statesmanship but the framework in which statesmen and citizens operate and the means by which they accomplish their common purposes." ${ }^{~}$ It becomes evident in light of this reality in Aristotle that, in the final accounting, the origins of law do not weigh heavily in considering the unity of ethics and politics. Law is the taken-for-granted precondition of all ethical-political thought and action; the political community, insofar as it is natural, does not seem to have a "starting point" in history or even thought, per se. ${ }^{61}$ Education, then, must be the crux of the ethical-political relationship. The role of the true statesman, Nichols argues on the basis of Aristotle, is to "educate partisans in his city about the partial justice of their opponents' claims." ${ }^{\text {"2 }}$ This is ultimately an education to moderation, the moral virtue that, by neither going to excess nor to deficiency, is itself in a sense a symbol or basis for moral virtue as such. Good ethics makes for good politics because a morally virtuous citizenry educated to be such by good statesmen exhibits an aversion to immoderate partisanship and faction.

\footnotetext{
${ }^{57}$ Historical examples abound: from the Inquisition to witch hunts to innumerable democratically imposed dictatorships and "political correctness," political consensus can hardly be said to ensure unqualifiedly choiceworthy results.

${ }^{58}$ Mary P. Nichols. Citizens and Statesmen: A Study of Aristotle's Politics. (Lanham: Rowman \& Littlefield Publishers, Inc., 1992), 154.

${ }^{59}$ Ibid 157.

${ }^{60}$ Ibid 169.

${ }^{61}$ Not even the classic social contract thinker, Thomas Hobbes, goes so far as to claim that the "state of nature" was an historical reality.

${ }^{62}$ Mary P. Nichols. Citizens and Statesmen: A Study of Aristotle's Politics. (Lanham: Rowman \& Littlefield Publishers, Inc., 1992), 176.
} 
The figure of the statesman and his importance for ethical politics provides a fitting conclusion when considering the pertinence of Aristotle for contemporary liberal democratic politics. In considering the statesman, it is helpful to return once more to Leo Strauss' idea of an informal aristocracy within a formal democracy. The very notion of aristocracy is offensive to the liberal democratic sensibility. To be sure, there are sound reasons for this; past "aristocracies" have rarely if ever been ruled by the truly virtuous, and have all too often been glorified fronts for oligarchies or plutocracies that cannot be passed off as just. Nonetheless, despite the evident improbability (not to say impossibility) of genuine aristocracy, the notion not necessarily of political rule by the virtuous few but of an individual who rules himself virtuously can be seen to provide some sort of remedy to the liberal bias in favour of freedom for freedom's sake. "Statesmen" as exceptional and exemplary human beings that provide educational models by their conduct are needed not necessarily to take charge of politics but to invoke the admiration and aspiration for greatness amongst citizens.

We cannot all be philosophers (to repeat Strauss' caution), but we can at least hope for a liberal democracy in which virtue is held up as a worthy goal. Again, the key is liberal education. The statesman as the morally and politically virtuous human being comes up short of the philosopher but is the peak of pre- or sub-philosophic excellence. We may not all be able to genuinely and adequately philosophize but, at the very least, we can all recognize and emulate the statesman. Liberal education provides the environment within which we are given the opportunity for this recognition; it gives us this opportunity by "reminding [us] of human excellence, of human greatness." ${ }^{3}$ Liberal democracy in its current form provides us with freedom, but with little to no guidance in determining how we ought to take full advantage of the fact that we are free and potentially rational beings. We must ask ourselves what freedom is for. Aristotle certainly did not endorse the position that all uses of freedom are equal as radical relativists and libertarians would argue, and we should not blindly accept the relativist-libertarian thesis, either. Liberal education is liberal insofar as it literally liberates or "frees" us of our more slavish traits, such as exclusive preoccupation with the baser desires; a human being that only pursues sex, food, and money is, in a sense, a natural slave as Aristotle conceived the term. By freeing ourselves from slavery to our lower desires, we become more naturally human; that is, we become logos-using, speech-making human beings. Liberal education liberates us from a narrow horizon by pointing us toward a more distant horizon, one that encompasses higher desires and ends. The liberally educated human being is both an ethical and a political human being; he is morally excellent, and he deliberates about the good life. The opportunity to live well within the political partnership by educating ourselves to be both ethical and political beings is what Aristotle has to offer us liberal democrats.

\section{Conclusion}

Ethics and politics as a single and unified project is dismissed as a more or less archaic and elitist notion in the age of liberal democracy. However, Aristotle makes a compelling case for this unity being not only real but something we ought to reconsider in relation to the way in which we do and think about politics in our age. By reviving virtue-based ethics and the view of politics as the partnership of logos-gifted and potentially rational beings pursuing the good in common within a political community ordered around the good, we are able to not only preserve stable liberal democratic regimes, but to improve said regimes by mixing in a taste of democracy

${ }^{63}$ Leo Strauss. Liberalism Ancient and Modern. (Chicago: University of Chicago Press, 1995), 6. 
as originally understood. We may do this for the sake of a regime in which citizens are free to free themselves or, to put it differently, for the sake of a regime in which excellence is not only possible but encouraged. 


\section{Bibliography}

Bartlett, Robert C. and Susan D. Collins. transls. Aristotle's Nicomachean Ethics. Chicago: University of Chicago Press, 2011.

Benardete, Seth and Michael Davis. transls. Aristotle - On Poetics. Indiana: St. Augustine's Press, 2002.

Bloom, Allan. The Closing of the American Mind. New York: Simon \& Schuster, 1987.

- - - transl. The Republic of Plato. New York: Basic Books, 1991.

Burger, Ronna. Aristotle's Dialogue with Socrates: On the Nicomachean Ethics. Chicago: University of Chicago Press, 2008.

Habermas, Jurgen. The Theory of Communicative Action, Vol. 1: Reason and the Rationalization of Society. Boston: Beacon Press, 1984.

Jaffa, Harry V. A New Birth of Freedom - Abraham Lincoln and the Coming of the Civil War. Lanham, Maryland: Rowman \& Littlefield, 2000.

Lilla, Mark. The Reckless Mind: Intellectuals in Politics. New York: The New York Review of Books, 2001.

Lord, Carnes. transl. Aristotle - The Politics. Chicago: University of Chicago Press, 1985.

Mansfield, Harvey C. A Student's Guide to Political Philosophy. Wilmington: ISI Books, 2001.

Nichols, Mary P. Citizens and Statesmen: A Study of Aristotle's Politics. Lanham: Rowman \& Littlefield, 1992.

Strauss, Leo. The City and Man. Chicago: University of Chicago Press, 1978.

- - Liberalism Ancient and Modern. Chicago: University of Chicago Press, 1995.

- - - Natural Right and History. Chicago: University of Chicago Press, 1950.

- - On Tyranny: Revised and Expanded Edition including the Strauss-Kojeve Correspondence. Chicago: University of Chicago Press, 2000.

- - - What is Political Philosophy? Chicago: University of Chicago Press, 1959.

Tessitore, Aristide. ed. Aristotle and Modern Politics - The Persistence of Political Philosophy. Notre Dame: University of Notre Dame Press, 2002.

Vickers, Brian. ed. Francis Bacon: The Major Works. New York: Oxford University Press, 
2008.

Wallach, John R. "Contemporary Aristotelianism” in Political Theory. Vol. 20, No. 4, 1992. 